\title{
2010s-25 \\ The Impact of Cigarette Tax Reduction on Consumption Behavior: Short-and Long-Term Empirical Evidence From Canada
}

\author{
Jean-François Ouellet, Mariachiara Restuccia, \\ Alexandre Tellier, Caroline Lacroix
}

\begin{tabular}{c}
\hline Série Scientifique \\
Scientific Series
\end{tabular}

\author{
Montréal \\ Mai 2010
}

(C) 2010 Jean-François Ouellet, Mariachiara Restuccia, Alexandre Tellier, Caroline Lacroix. Tous droits réservés. All rights reserved. Reproduction partielle permise avec citation du document source, incluant la notice $($ ).

Short sections may be quoted without explicit permission, if full credit, including (C) notice, is given to the source.
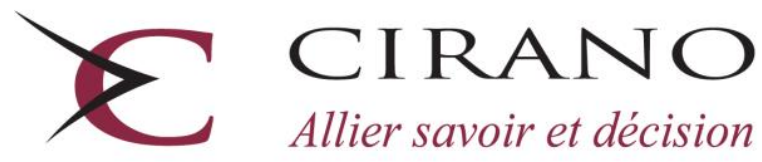

Allier savoir et décision

Centre interuniversitaire de recherche en analyse des organisations 


\section{CIRANO}

Le CIRANO est un organisme sans but lucratif constitué en vertu de la Loi des compagnies du Québec. Le financement de son infrastructure et de ses activités de recherche provient des cotisations de ses organisations-membres, d'une subvention d'infrastructure du Ministère du Développement économique et régional et de la Recherche, de même que des subventions et mandats obtenus par ses équipes de recherche.

CIRANO is a private non-profit organization incorporated under the Québec Companies Act. Its infrastructure and research activities are funded through fees paid by member organizations, an infrastructure grant from the Ministère du Développement économique et régional et de la Recherche, and grants and research mandates obtained by its research teams.

\section{Les partenaires du CIRANO}

Partenaire majeur

Ministère du Développement économique, de l'Innovation et de l'Exportation

\section{Partenaires corporatifs}

Banque de développement du Canada

Banque du Canada

Banque Laurentienne du Canada

Banque Nationale du Canada

Banque Royale du Canada

Banque Scotia

Bell Canada

BMO Groupe financier

Caisse de dépôt et placement du Québec

Fédération des caisses Desjardins du Québec

Gaz Métro

Hydro-Québec

Industrie Canada

Investissements PSP

Ministère des Finances du Québec

Power Corporation du Canada

Raymond Chabot Grant Thornton

Rio Tinto

State Street Global Advisors

Transat A.T.

Ville de Montréal

\section{Partenaires universitaires}

École Polytechnique de Montréal

HEC Montréal

McGill University

Université Concordia

Université de Montréal

Université de Sherbrooke

Université du Québec

Université du Québec à Montréal

Université Laval

Le CIRANO collabore avec de nombreux centres et chaires de recherche universitaires dont on peut consulter la liste sur son site web.

Les cahiers de la série scientifique (CS) visent à rendre accessibles des résultats de recherche effectuée au CIRANO afin de susciter échanges et commentaires. Ces cahiers sont écrits dans le style des publications scientifiques. Les idées et les opinions émises sont sous l'unique responsabilité des auteurs et ne représentent pas nécessairement les positions du CIRANO ou de ses partenaires.

This paper presents research carried out at CIRANO and aims at encouraging discussion and comment. The observations and viewpoints expressed are the sole responsibility of the authors. They do not necessarily represent positions of CIRANO or its partners. 


\title{
The Impact of Cigarette Tax Reduction on Consumption Behavior: Short-and Long-Term Empirical Evidence From Canada
}

\author{
Jean-François Ouellet", Mariachiara Restuccia ${ }^{\dagger}$, \\ Alexandre Tellier, Caroline Lacroix ${ }^{\S}$
}

\begin{abstract}
Résumé
De nombreuses études scientifiques ont été menées afin d'explorer le lien entre les taxes et la consommation des produits dérivés du tabac, plus en détail sur le fait d'arrêter de fumer. Bien que la plupart de la recherche ait été menée en comparant des niveaux statiques de taxation entre états ou pays, presque aucune étude n'a regardé les effets dynamiques des taxes, encore moins dans le contexte d'une réduction de taxes non homogène au sein d'un pays donné, en parallèle à certains phénomènes concomitants tels que le recours à la contrebande. De plus, la majorité des recherches n'ont pas adopté un cadre théorique contingent, tenant compte de certaines variables potentiellement influentes telles que l'âge des consommateurs et le niveau de consommation préalable.

En utilisant une base de données unique compilée par Statistique Canada, cette recherche estime plusieurs modèles qui explorent le comportement des consommateurs envers les cigarettes en lien avec une réduction des taxes de même qu'une série de facteurs individuels pouvant influencer ces comportements. Nous distinguons les effets dans le court terme - i.e. tout de suite après que les taxes aient été réduites - et dans le long terme - i.e. environ un an après que les taxes aient été réduites.

Nos résultats montrent que la consommation des cigarettes de contrebande est directement et fortement liée au niveau des taxes, et que ce comportement peut être diminué de façon efficace par une réduction des taxes. Une telle réduction explique quelque $17 \%$ de la décision d'un fumeur d'arrêter de consommer régulièrement des cigarettes de contrebande.

De plus, nos résultats montrent que les taxes ont un rôle très limité dans l'explication de la propension des individus à arrêter ou à commencer à fumer, surtout en comparaison avec l'âge et le niveau actuel de consommation. Nos analyses montrent que, malgré les effets statistiquement significatifs dus à la grande taille de l'échantillon, la portion du comportement du fumeur ou du non-fumeur qui est expliquée par les taxes est très petite. En d'autres termes, bien que les réductions de taxes sur les cigarettes abaissent la propension à arrêter de fumer ou à rester un fumeur, surtout à long terme, ces réductions expliquent environ un demi de $1 \%$ de cette décision. En comparaison, les modèles qui tiennent compte de l'âge du répondant ou, dans le cas des fumeurs, de la moyenne des cigarettes fumées par jour arrivent à expliquer de l'ordre de $5 \%$ à $10 \%$ du changement du comportement, soit 10 à 20 fois davantage que les taxes seules.
\end{abstract}

Ces résultats suggèrent que, malgré leur influence statistiquement significative sur les changements dans les comportements des fumeurs et des non-fumeurs, les réductions de taxes à partir d'un niveau initial aussi haut que 21 \$ par cartouche de 200 cigarettes ne sont pas des facteurs véritablement décisifs pour les modifications au comportement, autant dans le court que dans le long terme. En effet, quand les taxes sont si élevées, et dans un contexte où environ $20 \%$ de la population fume, les

\footnotetext{
* Jean-François Ouellet is Associate Professor of Marketing at HEC Montréal, email: jf.ouellet@ hec.ca

$\dagger$ Mariachiara Restuccia is a PhD candidate in Marketing at HEC Montréal.

* Alexandre Tellier is an MSc candidate in Marketing at HEC Montréal.

${ }^{\S}$ Caroline Lacroix is Assistant Professor of Marketing at UQAM.
} 
réductions des taxes n'incitent pas fortement les non-fumeurs à commencer à fumer ni n'incitent fortement les fumeurs à ne pas arrêter de fumer. Par contre, quand il est relativement facile de trouver sur le marché des produits de contrebande, ces réductions diminuent fortement la consommation de cigarettes de contrebande par les fumeurs. Ce résultat justifierait des recherches futures sur des moyens plus efficaces de mettre un frein au tabagisme, tels que les campagnes de marketing social cherchant à sensibiliser les consommateurs sur les dangers pour la santé (autant dans le court que dans le long terme) associés à la consommation de tabac.

Mots clés : Taxation, arrêter de fumer, tabac, économie comportementale

\begin{abstract}
Several academic studies have been conducted to explore the link between taxes on tobacco products and consumption behavior, especially smoking cessation. While most research has been conducted by comparing static levels of taxation across states or countries, almost none have looked at the dynamic effects of taxes, let alone the context of a tax decrease that is non-homogeneous within a given country, alongside parallel phenomena such as resort to smuggling. Moreover, most research has failed to adopt a contingency framework taking into account potentially influent variables such as age and consumption levels.

Using a unique dataset compiled by Statistics Canada, we estimate several models that explore consumers' behavior towards cigarettes as taxes are rolled back, their resort to consuming smuggled products, as well as a range of individual factors that influence said behaviors. We show effects in the very short term - that is, right after taxes are decreased - and in the long term — that is, a little over one year after taxes have been rolled back.

Our results suggest that consumption of smuggled cigarettes is directly and strongly linked to the level of taxes and that this behavior can be efficiently curbed by tax reduction. Tax cuts explain in the range of $17 \%$ a smoker's decision to stop regularly consuming smuggled cigarettes.

In addition, our results suggest that taxes themselves play a very limited role in explaining individuals' propensity to quit or to start smoking, especially in comparison with age and current smoking levels. Our analyses show that, despite statistically significant effects attributable to the large sample size, the part of a smoker or non-smoker behavior that is explained by taxes is very small. In other words, while cigarette tax cuts do reduce propensity to quit or to remain a non-smoker, especially in the long run, they are responsible for about $1 / 2$ of $1 \%$ of this decision. In comparison, models that take into account respondent age or, for smokers, the average number of cigarettes smoked daily, can explain in the order of 5\% to $10 \%$ the variation in behavior - that is, 10 to 20 times as much as taxes only.

These results suggest that, despite their statistically significant influence on smokers and non-smokers behavioral changes, tax cuts from an original level as high as $\$ 21$ on a carton of 200 cigarettes are not key short-term and long-term behavioral change agents - that is, when taxes are that high, and in a context where about $20 \%$ of the population does smoke, tax cuts neither strongly induce nonsmokers to start smoking nor strongly induce smokers not to quit smoking. However, they do, where smuggled products are readily available, strongly decrease smokers' consumption of smuggled cigarettes. This should warrant further investigation of more effective means to curb smoking in this context, such as societal marketing efforts raising awareness of the short-and long-term health hazards associated with smoking.
\end{abstract}

Keywords: Taxation, Smoking cessation, Tobacco, Behavioral Economics 
Introduction

Many countries and regions (e.g., states, provinces, territories) today impose taxes on tobacco products such as cigarettes and cigars (Loh 2009; Nikolay and lan 2005; Cavana and Tobias 2008; Marlow 2007). It is indeed believed that higher taxes should limit smoking prevalence and per capita consumption, conventional wisdom holding that a $10 \%$ to $14 \%$ increase in cigarette prices should lead to a 4-to $4.5 \%$ decline in smoking (Farrelly et al. 2008; Young 1983), at least in developed economies.

However, while price-elasticity has been usually studied unidirectionally-that is, in the case of price increase-little has been written about what happens when prices go down, such as when excise and/or other taxes are decreased. In addition, while most studies have considered relatively low taxation rates-e.g., in the order of $20 \%$ (Sung et al. 1994)-the literature has mostly avoided to question the constant nature of elasticity across groups and levels of pricing or taxation (an exception is Macki 2002), leaving out instances where tax rates may be as high as $40 \%$ as is the case in certain areas of Canada. For instance, while the first $10 \%$ price hike brought about by taxation might reduce consumption by $4 \%$, what about the second, third or even fourth such price increase? Finally, most literature has left out the fact that, as taxes increase, consumers may turn to smuggled products and contraband (Saba et al., 1995; Duffy, 2006). To address this concern, most research that has directly taken into account this displacement of demand toward illegal offerings has suggested levying federal excise taxes instead of state-level taxes, preventing illegal smuggling from one region to another within the country (Barnett et al., 1995; Lovenheim, 2008; Beatty, Larsen et al., 2009), a conclusion also prevalent in the context of other products subjected to sin-taxes such as alcohol (Levy and Sheflin, 1985).

To address these questions, we first review the literature pertaining to tax policy and its effects on consumption behavior in the case of tobacco products as well as in other so-called "sin product categories" such as alcohol. We then empirically investigate the effects of tax reductions in the high-tax context of 1994 Canada using longitudinal panel data from Statistics Canada and Health Canada. Following the presentation of results, we provide concluding remarks.

\section{The Impact of Tax Decrease on Tobacco Products Consumption}

Most legislations started taking action in relation to health hazards associated with tobacco consumption in the 1960's, 1970's, and 1980's, and only then started implementing measures to counter it (e.g., the California Tobacco Tax and Health Promotion Act of 1988). Most governments resorted to increasing excise and sales taxes on tobacco, oftentimes combining these tax hikes with additional measures such as bans on advertising and consumption in public spaces (Nicolás and Domínguez 2006), health warnings (Goel and Nelson 2006), and antismoking advertising (Peter and Nilss 1999). The effects of these policies have been largely investigated and reported in the economic, policy, and business literatures. However, few have 
specifically addressed the context of a tax decrease. What follows is therefore derived from general elasticity and behavioral economics literature.

The extent research shows mixed results regarding the effects of taxes on cigarette demand. While some conclude that demand elasticities with respect to home price are indistinguishable from zero (Lovenheim 2008), a rather large body of research concurs that cigarette price elasticity is significantly different from 0 . Looking specifically at tax policy in the context of Papua New Guinea, Chapman and Richardson (1990) report that an increase in excise tax between 1973 and 1986 has had a significant impact in reducing tobacco consumption. In the case of non-smokers, Berg and Kaempfer (2001) show that taxes are an efficient way to prevent from starting to smoke. In Canada, Nikolai and lan (2005) specify that short term and long term price elasticity for tobacco is -0.1 and -0.3 respectively. When controlling for smuggling by excluding the provinces and years where smuggling was greatest, the price elasticity for cigarettes in Canada found by Gruber et al. (2003) was between -0.47 and -0.45 , with sensitivity of smoking to price much larger among lower income Canadians. This, translated in the context of a tax decrease, provides us with a first research proposition:

\section{P1: At the individual level, the more important the decrease in cigarette taxes, (a) the higher the propensity to begin smoking and the lesser the propensity (b) to quit or (c) to reduce smoking.}

However, consumers may resort to alternatives instead of just quitting smoking, affecting the actual cigarette price-elasticity measurement. Four main such responses have been documented in the literature. First is cross-border purchasing. When smokers reside next to a regional (e.g., state, province) or international border where a large tax differential exists, consumers tend to buy these products where they are least expensive (Barnett et al., 1995; Lovenheim, 2008; Beatty, Larsen et al., 2009). Lovenheim (2008) shows that demand elasticities with respect to the home state price are indistinguishable from zero on average but vary significantly with the distance individuals live to a lower-price border. Second, consumers may also turn to substitute tobacco products. When taxes increase differentially between cigarettes and other tobacco products, consumers may partly or totally move their individual demand to less-taxed tobaccobased substitutes such as cigars, smokeless cigarettes, and hand-rolled cigarettes (Mindell et Whynes, 2000; Delnevo, Foulds et al, 2005; Tauras, Powell et al, 2007). They may also turn to cheaper brands to counter the effects of value-based taxes (Nicolás and Domínguez, 2006), and these effects have been shown to be strongest in younger consumers (Lois et al., 1998). Third, Adda and Cornaglia (2006) show that consumers may react to a tobacco tax increase by modifying their smoking behavior to take in more nicotine per cigarette smoked.

The most important mechanism however might be contraband. Flewelling et al. (1992), Gruber et al. (2003), and Duffy (2006) demonstrate that having access to a cigarette contraband network artificially increases cigarette price-demand elasticity. In studies that explicitly include contraband, the actual effects of tax increases on consumption are reduced (Baltagi and Levin, 
1986; Galbraith and Kaiserman, 1997). Moreover, cigarette contraband typically increases as taxes increase (Saba et al., 1995; Duffy, 2006) and with consumer access to other regions or jurisdictions where tobacco products are less expensive (Barnett et al. 1995; Meier et Licari 1997; Lovenheim, 2008; Beatty, Larsen et al, 2009). This is consistent with the literature pertaining to counterfeit products (Lai and Zaichkowsky 1999; Wilcox, Kim and Sen 2009), which holds that, for products yielding the same benefits, a lower-priced option will typically be considered despite the fact that it is illegal. It is also in line with the literature pertaining to addictive products, which contends that people will adapt their behavior to make the most of price shifts (Chen, Sun and Vishal 2009). In the context of a price decrease, the opposite behavior should be expected, giving us $\mathrm{P} 2$ :

\section{P2: At the individual level, within smokers, lower final taxes as well as a tax and/or price decrease should lead to (a) a higher propensity stop consuming smuggled cigarettes and (b) a lower propensity to start consuming smuggled cigarettes.}

Several other micro-level and macro-level factors also affect price-demand elasticity according to extent literature. At the individual-, micro-level, the current level of consumption appears to affect consumer responses to cigarette prices. Heavy smokers are less sensitive to price and thus will be less likely to change their consumption level in response to a price or tax change (Lois et al. 1998; Berg et Kaempfer, 2001; Goel et Nelson, 2006; Carpenter et Cook, 2008).

\section{P3: At the individual level, heavy smokers' behavior should be less affected by a tax and/or price decline than light smokers' behavior.}

Gender has also been shown to be a moderator of consumer responses to taxes on tobacco (Wasserman et al., 1991). When taxes increase, women tend to stop smoking altogether whereas men tend to reduce their consumption without completely stopping (Chaloupka 1992; Farrelly et al, 2001). Olgloblin and Brock (2003) have shown that female demand for tobacco products is more price-elastic then male demand for the same products.

\section{P4: At the individual level, in the case of a tax and/or price decrease, women's propensity to (a) start smoking; (b) not to quit smoking; or (c) increase their cigarette consumption should be higher than men's propensity to start, not to quit, or to increase smoking behavior.}

Finally, extent research holds that younger individuals are more price-sensitive than older consumers (Wasserman et al. 1991; Keeler, Hu et al, 2001). However, this could be related to income, which has also been studied as a potential moderator of consumer response to variations in cigarette prices, although without consensus. While some research argues that there is a positive relationship between consumer income and cigarette consumption (Andrews and Franke, 1991), others demonstrate the opposite (Baltagi and Levin 1986; Olgloblin and 
Brock, 2003). Some suggest that lower income consumers are more likely to smoke (Ahrens 2009), are more sensitive to prices (Lois et al. 1998; Gruber, Sen et al, 2003) and are more inclined to resort to contraband cigarettes (Lee et al. 2009), while others demonstrate that there is no significant difference between income groups (Farrelly, Engelen et al., 2008). At the macro level, the level of economic development of the region or country, in other words its level of richness, has been shown to affect cigarette consumption such that poorer countries tend to have higher smoking rates than richer ones (Chapman et Richardson 1990; van der Merwe et Abedian, 1999; Lance, Akin et al., 2004). In the context of a price decrease, this all gives us two additional propositions to be empirically explored:

P5: At the individual level, age should moderate the tax-tobehavior relationship postulated in P1 such that younger individuals should have a higher propensity (a) to start smoking, (b) increase smoking, or (c) not to quit smoking in the case of a tax and/or price decrease.

P6: At the individual level, income should moderate the tax-tobehavior relationship postulated in P1 such that lower-income individuals should have a higher propensity (a) to start smoking, (b) increase smoking, or (c) not to quit smoking in the case of a tax and/or price decrease.

Finally, exposition to societal, anti-tobacco advertising campaigns (Abernethy et Teel 1986, Wasserman et al. 1991; Novotny et al. 1996; Baltagi et Levin 1986; Kaiserman et Rogers 1991; Seldon et Boyd 1991; Wasserman et al., 1991; Hu et al. 1995) have also been studied and have been shown, with a certain consensus, to increase consumers' sensitivity to taxes. In addition, other scholarly research has shown that anti-tobacco sentiment in a population does affect general price-demand elasticity, but it is hard to control for as it appears to be highly correlated with cigarette price and taxes (Keeler, Hu et al, 2001; Lance, Akin et al, 2004; Alamar et Glantz, 2006; Marlow, 2007). In other words, jurisdictions that most tax tobacco are also the ones where anti-tobacco sentiment is highest. This should mean that a decrease in tax should not have much influence given the general anti-tobacco sentiment that prevails in high-tax environments. To the contrary, however, Macki (2000) argues that price-demand elasticity increases with higher levels of taxation. In other words, where prices and/or taxes are initially high, a tax and/or price decrease should have more effects than in locations where prices and/or taxes are initially lower. This gives us a last proposition:

P7: At the individual level, in the case of a tax cut, higher initial tax levels should translate into a higher propensity (a) to start smoking, (b) increase smoking, or (c) not to quit smoking than lower initial tax levels. 
In February 1994, the Canadian Federal Government cut its excise tax from $\$ 10.36$ to $\$ 5.36$ per carton of 200 cigarettes in an effort to curb demand for tobacco smuggled across the border from the United States. By April 1994, five out of 10 Canadian provinces had also cut their own sales taxes, the Federal Government then cutting further its excise tax in these provinces. As Musgrave and Stern (1988) have shown, in a context where contraband, smuggling, and more generally a black market are present, an efficient solution can be as simple as lowering taxes. Table 1 shows the effects of these cuts on cigarette price, per province.

Table 1

Cigarette tax rates per carton of 200 cigarettes

\begin{tabular}{lcrl}
\hline & \multicolumn{2}{c}{ Year; Tax rate (\$) } & \\
\cline { 2 - 3 } Province & 1993 & 1994 & Date of change \\
\hline Provinces where provincial & & & \\
taxes were cut & & & \\
Quebec & 29.61 & 8.61 & February 1994* \\
New Brunswick & 29.45 & 15.45 & February 1994 \\
Ontario & 28.85 & 9.65 & February 1994² \\
Prince Edward Island & 35.45 & 21.20 & March 1994 \\
Nova Scotia & 29.45 & 15.45 & April 1994 \\
Provinces where provincial & & & \\
taxes were not cut & & & \\
Newfoundland & 36.41 & 31.41 & NA \\
Manitoba & 31.85 & 26.85 & NA \\
Saskatchewan & 31.85 & 26.85 & NA \\
Alberta & 29.85 & 24.85 & NA \\
British Columbia & 37.85 & 32.85 & NA \\
\hline
\end{tabular}

*The tax rate in Quebec subsequently increased, reaching \$10.81 in May 1995.

${ }^{2}$ The tax rate in Ontario subsequently increased, reaching \$10.85 in Feb. 1995.

${ }^{3}$ The tax rate in PEI was further reduced to $\$ 19.20$ in June 1994.

$\mathrm{NA}=$ Not applicable

Source: Hamilton et al. (1997), p. 188

The strategy seemed to pay off ; by 2001, the Royal Canadian Mounted Police reported seizures of slightly less than 29,000 cartons of illegal cigarettes, from a high of over 456,000 such cartons in 1994 (RCMP 2010). In value, the market for contraband cigarette in Canada had steeply declined, from \$92.9 million in 1997 to \$4.7 million in 1999 (Gillespie 2000). However, as 
provinces increased tax levels back to their pre-1994 levels, in 2000, cigarette smuggling resurfaced, the RCMP seizing nearly 966,000 cartons in 2008 alone (see Figure 1 ).

Figure 1.

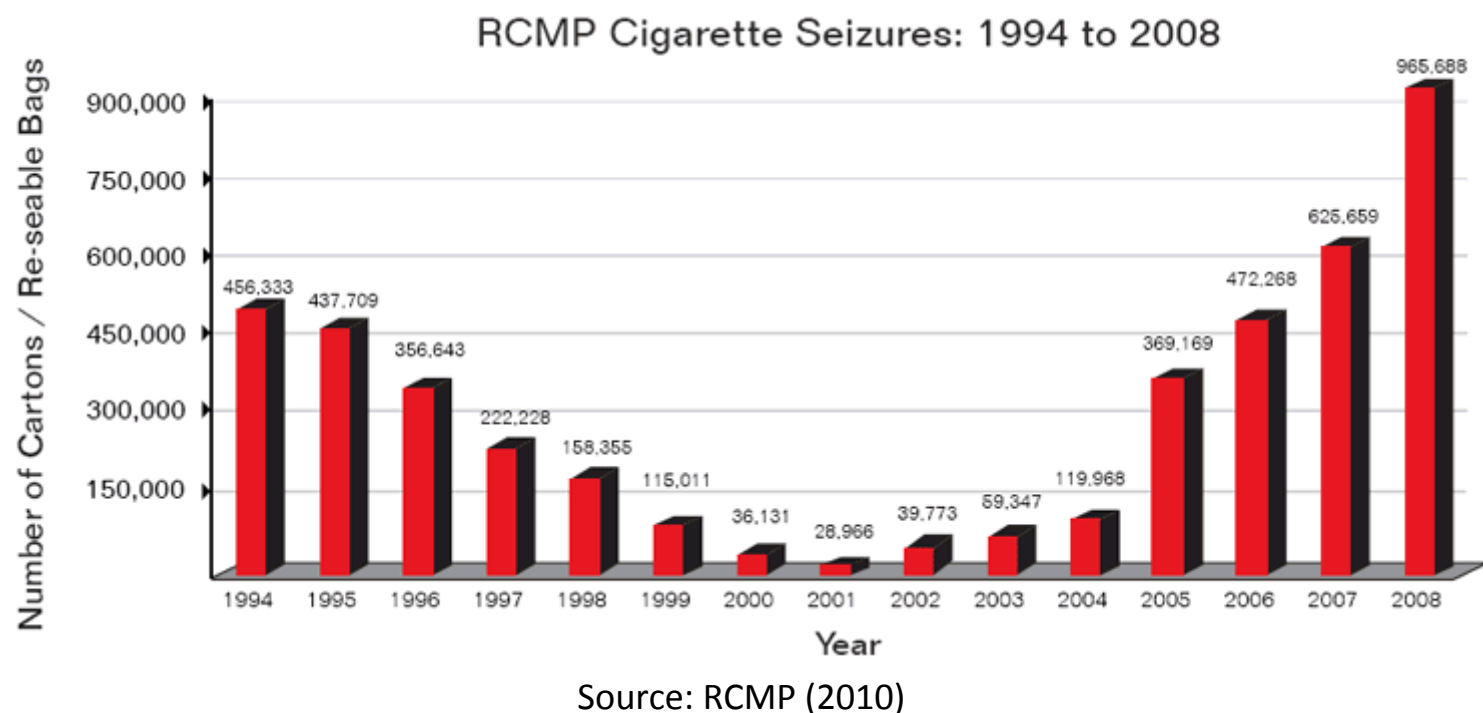

In 1994, as taxes were being rolled back, several groups in Canada expressed concern that a tax decrease could trigger negative consequences in tobacco consumption and prevalence (e.g. Gray 1994). To better monitor the situation and the impacts of this tax rollback, Health Canada commissioned Statistics Canada to survey smoking behavior of a large panel of Canadians through a 1-year longitudinal study, between January 1994 and February 1995.

This survey was designed to provide a representative sample of Canadians aged 15 years and older (excluding those living in institutions) using random-digit dialing (see Statistics Canada (1994) for details). It was conducted in 4 cycles, the first of which took place between April 20 and June 1, 1994. In the first cycle, respondents were asked about their smoking status in January 1994, just before federal and provincial tax cuts were implemented, as well as their current smoking status - that is, 3-4 months after tax cuts. The second and third cycles repeated questions about smoking habits and were conducted between August 16 and Sept. 16, 1994 as well as between November 14 and December 14, 1994 respectively. The fourth and final cycle took place between February 15 and March 16, 1995-that is, 13-14 months after tax rollbacks.

In the first cycle, a total of 15,804 Canadians were surveyed with a special emphasis on younger and lower-income groups in the population, believed to be more vulnerable to tobacco price and/or tax cuts. By the fourth cycle, 4,685 respondents had been lost, yielding a total of 11,119 individuals who had responded to all 4 cycles. Table 2 provides descriptive statistics for this sample. 
Table 2.

Descriptive Statistics of Sample

\begin{tabular}{|c|c|c|}
\hline & $\begin{array}{r}\text { Number of } \\
\text { respondents }\end{array}$ & Percentage \\
\hline \multicolumn{3}{|l|}{ Province } \\
\hline Newfoundland & 821 & 7.4 \\
\hline Prince Edward Island & 269 & 2.4 \\
\hline Nova Scotia & 746 & 6.7 \\
\hline New Brunswick & 867 & 7.8 \\
\hline Québec & 2011 & 18.1 \\
\hline Ontario & 2037 & 18.3 \\
\hline Manitoba & 771 & 6.9 \\
\hline Saskatchewan & 742 & 6.7 \\
\hline Alberta & 901 & 8.1 \\
\hline British Columbia & 1954 & 17.6 \\
\hline \multicolumn{3}{|l|}{ Gender } \\
\hline Male & 4939 & 44.4 \\
\hline Female & 6180 & 55.6 \\
\hline \multicolumn{3}{|l|}{ Age } \\
\hline 15-19 Years & 2273 & 20.4 \\
\hline 20-24 Years & 1608 & 14.5 \\
\hline 25-34 Years & 1474 & 13.3 \\
\hline 35-44 Years & 1334 & 12.0 \\
\hline 45-54 Years & 689 & 6.2 \\
\hline 55-64 Years & 691 & 6.2 \\
\hline 65-69 Years & 1117 & 10.0 \\
\hline $70+$ Years & 1933 & 17.4 \\
\hline \multicolumn{3}{|l|}{ Revenues in 1993} \\
\hline Less than $\$ 20,000$ & 2488 & 22.4 \\
\hline$\$ 20,000-\$ 39,999$ & 3183 & 28.6 \\
\hline$\$ 40,000-\$ 59,999$ & 1759 & 15.8 \\
\hline$\$ 60,000-\$ 79,999$ & 806 & 7.2 \\
\hline$\$ 80,000$ or more & 709 & 6.4 \\
\hline DNK/DNA & 2174 & 19.6 \\
\hline
\end{tabular}


Several questions were asked to respondents across all four cycles, many of which are of interest in order to explore our research propositions. First, Statistics Canada asked respondents about their smoking status in January of 1994, before taxes were cut ("smoker," "non-smoker"), as well as at the beginning of each cycle ("everyday," "occasionally," "never"). These latter variables were recoded to be comparable with the smoking status in January of 1994 so that everyday and occasional smokers were recoded as smokers while "never" was recoded as nonsmoker. This enabled Statistics Canada to compute a short-term behavioral modification variable between January and May of 1994 (i.e., remained a smoker, remained a non-smoker, started smoking, quit smoking) and makes it possible to compute a long-term behavioral modification variable between January 1994 and March 1995. On top of sociodemographic data, Statistics Canada also gathered information about respondents' regular resort to smuggling and cross-border cigarettes consumption before and after tax cuts ("Used to before tax cuts but no longer do," "Did not use to but began after taxes were cut," "Did before and after tax cuts," "Never did") as well as average daily consumption of cigarettes in May 1994 and in March 1995-that is, both shortly after and one year after taxes had been cut. Table 3 provides statistics for all of these variables. We finally augmented this data set with information pertaining to taxes themselves, their initial levels, their final levels (the lowest one in the cases where provinces had more than one single tax-level variation) as well as the tax decrease for the province, in dollars and as a percentage of the initial level.

To empirically explore how our propositions are supported by this data, we estimated a series of univariate and multivariate binary logistic regression models using SPSS/PASW Statistics version 18. The following section provides the results of these analyses.

Results

The main effects of tax cuts on smoking behavior change

To investigate the univariate effects of tax levels on smoking behavior, we conducted several analyses. First, to compare January 1994 smokers who had quit smoking to those who had not, we selected smokers as per January 1994 (prior to tax cuts) -that is, 2,691 still-smokers to be compared with the 160 (5.6\% of total) former smokers who had quit by May 1994. Despite this large discrepancy, we elected not to randomly under-sample the number of still-smokers since the database was large enough following Peduzzi et al. (1996) and Long (1997). 
Table 3.

Descriptive Statistics of Smoking Behaviors in Sample

\begin{tabular}{|c|c|c|}
\hline & $\mathrm{N}$ & $\%$ \\
\hline \multicolumn{3}{|l|}{ Short-term (Jan-May 1994) } \\
\hline Remained non-smoker & 8129 & 73,1 \\
\hline Quit smoking & 160 & 1,4 \\
\hline Remained smoker & 2691 & 24,2 \\
\hline Started smoking & 61 & 0,5 \\
\hline Missing & 78 & 0,7 \\
\hline \multicolumn{3}{|l|}{ Long-term (Jan 1994-May 1995) } \\
\hline Remained non-smoker & 7890 & 71,0 \\
\hline Quit smoking & 596 & 5,4 \\
\hline Remained smoker & 2255 & 20,3 \\
\hline Started smoking & 300 & 2,7 \\
\hline Missing & 78 & 0,7 \\
\hline \multicolumn{3}{|l|}{ Regularly bought in U.S.A./contraband } \\
\hline U.S.A./contr. before tax cuts & 306 & 13,9 \\
\hline U.S.A./contr. after tax cuts & 37 & 1,7 \\
\hline U.S.A./contr. both before/after tax cuts & 129 & 5,8 \\
\hline Neither before nor after tax cuts & 1736 & 78,6 \\
\hline Not applicable & 8911 & \\
\hline Average number of cig. daily (May 1994) & 15,0 & \\
\hline Average number of cig. daily (May 1995) & 14,1 & \\
\hline
\end{tabular}

We first estimated four univariate logistic regression models with short- or long-term status ("smoker" vs. "non-smoker") with a dummy variable as a predictor, which took the value " 1 " if taxes had been cut within the province of residence, and " 0 " otherwise. The event of interest was to have become or to have remained a non-smoker. As Table 4a suggests, the mere fact of lowering taxes reduced smokers' propensity to quit in the short-term $(p<.05)$ and non-smokers' propensity to remain a non-smoker in the long-run $(p<.01)$. Non-smokers' propensity to remain non-smokers in the short-term was also marginally significantly affected by tax cuts $(p<.10)$ but not smokers' long-term propensity to stop smoking ( $\mathrm{p} \geq .10)$.

However, despite statistical significance, these results are mitigated by the fact that only fractions of the phenomena are explained by tax cuts, as suggested by the low Nagelkerke pseudo- $\mathrm{R}^{2}$, all below 6 tenth of one percent. Moreover, despite such a large sample size, $\mathrm{p}$ values associated with the variables are rather high, suggesting that the effects are not so clearcut. In fact, since an overwhelming majority of non-smokers did remain non-smokers, the same stagnation also being found in smokers, taxes themselves appeared to play a very small role in smokers' and non-smokers' decision to change their behavior. 
Table 4a.

Smokers and non-smokers' propensity to quit/start smoking according to tax cuts (IV: "taxes cut"/"not cut"; only significant or marginally significant results shown)

\begin{tabular}{lccrr}
\hline Dependent & B(S.E.) & Wald(df) & Exp(B) $\begin{array}{r}\text { Nagelkerke } \\
\mathrm{R}^{2}\end{array}$ \\
\hline Smokers' Short-Term Propensity to Become NS & $-.411(.163)$ & $6,342(1)^{*}$ & .663 & .006 \\
Smokers' Long-Term Propensity to Become NS & $-.113(.092)$ & $1,504(1) \not \mathbb{}$ & .893 & .001 \\
Non-Smokers' Short-Term Propensity to Remain NS & $-.477(.268)$ & $3,181(1)^{\dagger}$ & .620 & .005 \\
Non-Smokers' Long-Term Propensity to Remain NS &.$- .376(.121)$ & $9,714(1)^{* *}$ & .687 & .004 \\
\hline
\end{tabular}

$$
* * p<.01 ; * p<.05 ;+p<.10 ; \text { < n.s. }
$$

To investigate further the effects of tax cut depth on consumption behavior, we estimated a short-term univariate binary logistic regression model with May 1994 smoking status as a dependent variable and the tax cut (in CAD\$) as the unique predictor. The event of interest was for the dependent variable to take the value "being a non-smoker." We replicated the same analysis with the long-term, March 1995 smoking status as a dependent variable. Finally, we estimated the effects of the same predictor on non-smokers' propensity to start smoking, once again both in the short- and long-term, by replicating the same analyses after having first, this time, singled out those who declared to be non-smokers in January 1994 (prior to tax cuts).

Table 4b.

Smokers and non-smokers' propensity to quit/start smoking according to taxes (only significant or marginally significant results shown)

\begin{tabular}{|c|c|c|c|c|c|c|c|c|}
\hline Model & Predictor & B & S.E. & Wald(df) & Sig. & $\operatorname{Exp}(B)$ & $\begin{array}{r}\text { Hosmer \& } \\
\text { Lemeshow }\end{array}$ & $\begin{array}{r}\text { Nagelkerke } \\
/ \text { Cox \& } \\
\text { Snell } R^{2}\end{array}$ \\
\hline \multirow{4}{*}{ 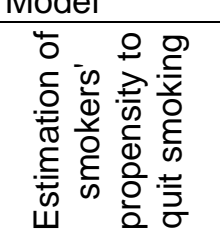 } & \multicolumn{6}{|c|}{ Short-term Model } & \multirow[t]{2}{*}{$2.214(3)^{a}$} & \multirow[t]{2}{*}{$.002 / .005$} \\
\hline & Tax cut $(\$)$ & -.027 & .012 & $5.067(1)$ & .024 & .974 & & \\
\hline & \multicolumn{6}{|c|}{ Long-term Model } & \multirow[t]{2}{*}{$11.386(3)^{* *}$} & \multirow[t]{2}{*}{$.001 / .002$} \\
\hline & Tax cut $(\$)$ & -.013 & .007 & $3.996(1)$ & .046 & .987 & & \\
\hline \multirow{4}{*}{ 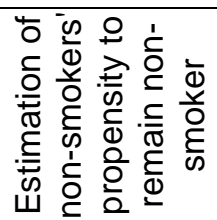 } & \multicolumn{6}{|c|}{ Short-term Model } & \multirow[t]{2}{*}{$1.311(2) a}$. & \multirow[t]{2}{*}{$.000 / .003$} \\
\hline & Tax cut $(\$)$ & -.029 & .019 & $2.331(1)$ & .127 & .972 & & \\
\hline & \multicolumn{2}{|c|}{ Long-term Model } & & & & & \multirow[t]{2}{*}{$8.220(2)^{*}$} & \multirow[t]{2}{*}{$.001 / .003$} \\
\hline & Tax cut $(\$)$ & -.020 & .009 & $5.606(1)$ & .018 & .980 & & \\
\hline
\end{tabular}

As shown in Table 4b, tax cuts were found to be significant and negative predictors of smokers' propensity to quit smoking in the short-term and in the long-term $(p<.05)$. The models suggest that each additional dollar in tax cuts translated into respectively $2.6 \%$ and $1.3 \%$ less likelihood 
of smoking cessation in the short- and long-term. However, with pseudo- $\mathrm{R}^{2}$ statistics below 005 and a significant Hosmer and Lemeshow Goodness-of-Fit Test in the long-term model, these effects, despite being statistically significant, really explain but a tiny fraction (i.e., less than $0.5 \%)$ of smokers' decision to quit smoking. This, combined with the rather high $p$-values considering the size of the sample, should warrant caution in the interpretation of results.

In the case of non-smokers, tax cuts were found not to play a role in the short-term propensity to remain a non-smoker but were found to be a significant and negative predictor of same propensity in the long-term ( $p<.05)$, with each dollar in tax cuts reducing by $2.0 \%$ the propensity to remain a non-smoker a year after tax cuts. However, a significant Hosmer and Lemeshow Goodness-of-Fit Test as well as low pseudo- $\mathrm{R}^{2}$ statistics (i.e., .003 and less) suggest that, again, these results should be taken with caution as they seem to reflect a very small proportion (i.e., about $0.3 \%$ ) of non-smokers' long-term propensity to remain non-smokers. This, again combined with the rather high $p$-value considering the size of the sample, provides weak support to our first two sub-propositions $\mathrm{P} 1 \mathrm{a}$ and $\mathrm{P} 1 \mathrm{~b}$, this support coming with serious limitations.

To examine the effects of taxes on smokers' cigarette consumption postulated in P1c, we first computed a new variable representing the difference between the average number of cigarettes smoked daily in May 1994 and in March 1995. We then estimated a univariate linear regression model with this new variable as a dependent and tax cuts (in \$) as the predictor. The resulting model was not statistically significant and failed to reveal a significant link between tax cuts and any modification in cigarette consumption levels for the 2,200 smokers for which cigarette consumption levels in 1994 and 1995 were available. This failed to provide support for P1c and we cannot conclude, based on the data gathered by Statistics Canada in 1994, that tax cuts could increase smoking consumption levels.

The influence of taxes on smuggled cigarettes consumption

To assess whether taxes on tobacco and their decrease could be linked to consumption of smuggled or foreign-bought cigarettes, we first singled out those who declared having regularly consuming smuggled or foreign-bought cigarettes before taxes were cut $(N=435)$ and computed a new variable that took the value 0 if the respondent had declared not having changed his smuggling behavior after taxes were rolled-back $(N=129)$ and that took the value 1 if the respondent had declared having stopped $(N=306)$. We then estimated two univariate binary logistic regression models with this new binary variable as a dependent and with the final applicable taxes as well as the applicable tax cut as the predictors. As Table 5 shows, the models provided good fit for the data (Hosmer and Lemeshow Test: $p>$.10) and explained between $11.9 \%$ and $17.0 \%$ of the phenomenon. Both tax cuts and the final applicable tax levels were significant and strong predictors of cessation to regularly buy smuggled or U.S.-imported cigarettes $(p<.001)$. Each additional dollar of final applicable sales tax decreased by $8.7 \%$ the 
likelihood of stopping smuggling while each additional dollar in tax cuts increased by $13.2 \%$ the likelihood of ending regular consumption of smuggled cigarettes.

Table 5.

The effects of taxes and tax cuts on consumption of smuggled and foreign-bought cigarettes

\begin{tabular}{|c|c|c|c|c|c|c|c|}
\hline Predictor & B & S.E. & Wald(df) & Sig. & $\operatorname{Exp}(B)$ & $\begin{array}{l}\text { Hosmer \& } \\
\text { Lemeshow }\end{array}$ & $\begin{array}{r}\text { Cox \& Snell } \\
\text { Nagelkerke } \\
\mathrm{R}^{2}\end{array}$ \\
\hline \multicolumn{8}{|c|}{$\begin{array}{l}\text { Dependent: Stopping regular purchase of smuggled cigarettes (in those who did prior } \\
\text { to tax cuts) }\end{array}$} \\
\hline $\begin{array}{l}\text { Final Taxes } \\
(\$)\end{array}$ &,- 091 & ,013 & $51.297(1)$ & *** & ,913 & $1.211(3) a$ & 170 / 119 \\
\hline Tax cut $(\$)$ & ,124 &, 017 & $50.981(1)$ & $* * *$ & 1,132 & $5.411(4) \mathfrak{a}$ &, $117 / .167$ \\
\hline \multicolumn{8}{|c|}{$\begin{array}{l}\text { Dependent: Starting regular purchase of smuggled cigarettes (in those who did not } \\
\text { prior to tax cuts) } \\
\text { Final Taxes }\end{array}$} \\
\hline (\$) & .050 & .019 & $6.896(1)$ & .009 & 1.051 & $13.809(5)^{*}$ & ,004 / .023 \\
\hline Tax cut $(\$)$ & -.061 & .027 & $5.012(1)$ & .025 & .941 & $.078(3) a$ & $.003 / .017$ \\
\hline
\end{tabular}

We also conducted the reverse analysis by singling out smokers who declared not having regularly consumed smuggled or foreign-bought cigarettes before taxes were cut $(N=1,773)$ and computed a new variable that took the value " 0 " if the respondent had declared not having changed his smuggling behavior after taxes were rolled-back $(N=1,736)$ and that took the value " 1 " if the respondent had declared having started $(N=37)$. Despite the large discrepancy in the preceding numbers of respondents having adopted the two types of behavior regarding consumption of smuggled cigarettes, the number of valid respondents was sufficient to conduct the analysis without under-sampling those who had not changed their behavior (Peduzzi et al. 1996). We then estimated two univariate binary logistic regression models with this new binary variable as a dependent and with the final applicable tax rate and the applicable tax cut in dollars respectively as predictors.

The models had weaker fit to the data, with pseudo $\mathrm{R}^{2}$ in the order of .02 at best and, in the case of the model with final applicable taxes as the predictor, a significant Hosmer and Lemeshow Goodness-of-Fit Test. Both variables were found to be significant predictors of the propensity to resort to smuggling in those who had not already done so prior to tax cuts. Each additional dollar in final applicable taxes raised by $5.1 \%$ the propensity to resort to smuggling while each additional dollar in tax cuts decreased it by $5.9 \%$. In other words, the higher the taxes, the lesser the likelihood to stop smuggling or to stop consuming smuggled cigarettes or, although in a much more limited way, the higher the likelihood to begin smuggling or consuming smuggled cigarettes. Also, the deeper the tax cuts, the higher the likelihood to stop smuggling or buying smuggled cigarettes or, although in a more limited way, the lesser the likelihood to start 
smuggling or buying smuggled cigarettes. However, relatively high p-values despite the large sample size, as well as pseudo- $\mathrm{R}^{2}$ statistics inferior to $5 \%$ suggest that these last results should be interpreted with caution. Overall, this provides strong support for P2a as well as weak support for P2b.

The multivariate effects of taxes and tax cuts on smoking behavior change

Before examining the various postulated effects through univariate analyses, we examined the effects of tax rollbacks on smokers' propensity to quit smoking and on non-smokers' propensity to remain non-smokers, alongside every single moderator postulated above, through a multivariate model. By eliminating respondents with missing values, we had a sample consisting of 2,265 smokers (none of which had quit by May 1994 and 391 of which had done so by March 1995) and 6,536 non-smokers (45 of which had started smoking by May 1994 and 229 of which had done so by March 1995). A short-term analysis of smoking cessation could not be performed because of lack of cases, and because in the order of 15,525 respondents would have been needed to confidently assess the short-term propensity to remain non-smokers (Peduzzi et al. 1996), only long-term models were estimated.

Table 6.

Multivariate models of smoking cessation or non-smoking continuity

\begin{tabular}{|c|c|c|c|c|c|}
\hline Model / Predictor & $B(S . E)$. & Wald (DF) & $\operatorname{Exp}(B)$ & $\begin{array}{r}\text { Nagelkerke } \\
\mathrm{R}^{2}\end{array}$ & $\begin{array}{l}\text { Hosmer \& } \\
\text { Lemeshow }\end{array}$ \\
\hline \multicolumn{4}{|c|}{ Smokers' Long-Term Propensity to Become NS } & .098 & $16.771(8)^{*}$ \\
\hline Tax cuts $(\$)$ & $-.086(.038)$ & $5.416(1)^{*}$ & .917 & & \\
\hline Final applicable taxes (\$) & $-.061(.026)$ & $5.609(1)^{*}$ & .941 & & \\
\hline Tax cuts $\times$ Final Appl. Taxes & $.004(.002)$ & $4.320(1)^{*}$ & 1.004 & & \\
\hline Age $\times$ Tax cuts & $-.004(.002)$ & $4.474(1)^{*}$ & .996 & & \\
\hline Average Num. of Cig. / day & $-.072(.007)$ & $102.230(1)^{* * *}$ & .931 & & \\
\hline \multicolumn{4}{|c|}{ Non-smokers' Long-Term Propensity to Remain NS } & .080 & $3.422(8) \mathrm{a}$ \\
\hline Tax cuts $\times$ Final Appl. Taxes & $-.005(.002)$ & $5.166(1)^{*}$ & .995 & & \\
\hline Age $\times$ Tax cuts & $.019(.009)$ & $4.418(1)^{*}$ & .995 & & \\
\hline $\mathrm{Age}^{2}$ & $.046(.010)$ & $21.117(1)^{* * *}$ & 1.047 & & \\
\hline Age $^{2} \times$ Tax cuts & $-.003(.001)$ & $4.060(1)^{*}$ & .997 & & \\
\hline
\end{tabular}

A stepwise, backward-elimination procedure was used to estimate the two models. In the longterm, smokers' propensity to quit smoking was affected by 5 variables. The model explained $9.8 \%$ of the phenomenon according to Nagelkerke pseudo- $\mathrm{R}^{2}$, but fit of the model to the data 
was not satisfactory (Hosmer and Lemeshow goodness-of-fit test; $p<.05$ ), suggesting caution in interpreting the following results. Tax rollbacks, final levels of applicable taxes, and interaction of tax rollbacks with age and final applicable tax levels suggested a complicated relationship between propensity to quit smoking and tax cuts. As expected, tax cuts themselves were negatively related to smokers' propensity to quit smoking $(p<.05)$. However, the final level of applicable taxes was also a significant and negative predictor of propensity to quit smoking, suggesting that smokers tended to quit less where final taxes remained high $(p<.05)$. In conjunction with the interaction term between final applicable taxes and tax cuts, this all suggested that tax cuts had mitigated effects on reducing cessation propensity where taxes were lowest in the end. For instance, everything considered, in comparison with a smoker residing in another province, a smoker living in a province where tax cuts were \$1 deeper and where final applicable taxes where $\$ 1$ lower had a $2.9 \%$ lesser likelihood of quitting smoking.

Tax cuts also interacted with age such that tax cuts had more of a negative impact on older smokers' short-term propensity to quit smoking than on younger consumers' same propensity $(p<.05)$. The preceding factors - age, tax cuts, final level of taxes - all had rather high $p$-values considering the size of the sample at hand, suggesting very limited effects in reality. Somewhat confirming this limited effects of these last variables, when estimating a model with only these variables as predictors, the Nagelkerke pseudo- $\mathrm{R}^{2}$ falls to .014 .

The one predictor that was highly significant was the average number of cigarettes smoked daily which, notwithstanding taxes, clearly drove smokers' propensity to quit such that the more cigarettes people smoked, the less likely they were to quit. Table 6 summarizes these results.

In the case of non-smokers, tax cuts again seemed to play a somewhat complicated role, not affecting behavior directly but rather in interaction with the final applicable level of taxes and with age. Tax cuts indeed counter-intuitively interacted with the final applicable level of taxes such that when cuts were deeper but final applicable taxes remained high, a non-smoker's propensity to remain a non-smoker decreased $(p<.05)$. In comparison with a non-smoker residing in another province, a non-smoker living in a province where taxes were cut $\$ 1$ deeper and thus ended up $\$ 1$ lower in the end had a $0.5 \%$ higher chance of remaining a non-smoker.

$\mathrm{Age}^{2}$ however was the most significant predictor of non-smokers' propensity to remain nonsmokers such that younger and older non-smokers tended to be the least likely to remain nonsmokers, middle-aged non-smokers being the most likely to remain non-smokers in the longterm $(p<.001)$. Tax cuts interacted with age such that a $\$ 1$ tax cut had more effects in older nonsmokers than on younger non-smokers, again contrary to what was expected based on previous literature.

Having examined the multivariate effects of various variables on smoking behavior, we were also interested in investigating more in depth the univariate effects of the same variables. The main reason to push our analysis further was to contrast the long-term effects and short-term effects, which could not be addressed in a multivariate way. 
The moderating influence of prior smoking level

To investigate how prior smoking level affected tax-level efficiency in reducing smoking behavior, we conducted several analyses. Because Statistics Canada did not solicit information about smoking levels prior to tax cuts, we had to limit this exploration to the long-term interaction effects of smoking levels and tax levels in respondents who were still smokers in May of 1994, shortly after taxes had been cut. We also had to use smoking level in May 1994 as a proxy of smoking level 5 months earlier, prior to tax cuts.

We singled out those who declared to be smokers in January 1994 (prior to tax cuts) for which we had information about smoking level in cycle 1, yielding 2,262 respondents of which 488 had stopped smoking by May 1995. Despite this large discrepancy in the number of respondents in each group, the sample size was sufficient to conduct a valid analysis (Peduzzi et al. 1996). We then estimated a short-term binary logistic regression model with May 1995 smoking status as a dependent variable and the applicable tax cut in CAD\$ as a predictor, the average number of cigarettes smoked daily in May 1994 as a covariate, and an interaction effect between the two factors. The event of interest was for the dependent variable to take the value "being a nonsmoker" and we used a stepwise, backward-elimination estimation procedure using Wald's method.

As shown in Table 7a, after backward elimination, only the original smoking level (in May 1994) was a significant predictor of smokers' propensity to quit smoking. For each additional cigarette smoked on a daily basis in May 1994, the propensity to have ceased smoking by March 1995 decreased by $7.6 \%(p<.001)$. A look at the models before backward elimination of the least significant variable at each step shows that this predictor was highly significant at each step $(p<.001)$ and that neither tax cuts nor its interaction term with prior smoking level were significant in any of the steps ( $p>.10$ ). The final model explains between $6.5 \%$ and $10.5 \%$ of the phenomenon.

However, a significant Hosmer and Lemeshow Goodness-of-Fit Test suggested caution in the interpretation of these results. We thus investigated further the role played by previous smoking levels on propensity to stop smoking. The data suggested that this behavior could be driven by a higher-order function of the number of daily cigarettes. We therefore computed two additional variables consisting in the power of 2 and the power of 3 of the number of cigarettes smoked daily in May 1994. We ran a model explaining the propensity to quit smoking by May 1995 on the basis of average smoking level in May 1994, its square and cubic values, as well as interaction terms of these three variables with tax cuts, which was also included as a direct predictor. Again, a stepwise backward-elimination procedure using Wald's method was used and converged after 3 iterations. As can be seen at the bottom of Table 6 , the Hosmer and Lemeshow test confirms that the model is now a good fit to the data while the pseudo- $\mathrm{R}^{2}$ statistics confirm that between $7.7 \%$ and $12.5 \%$ of the behavior is now accounted for by the 
model. Tax cuts themselves are still not a significant predictor of behavior but rather a moderator of the effects of previous smoking levels on the propensity to stop smoking in the long-term. The first-, second- and third-order terms suggest that, while the propensity to quit smoking does decrease with a higher daily consumption of cigarettes $(p<.001)$, it does not do so linearly and is affected by the level of tax cuts.

Table $7 \mathrm{~b}$ shows a number of scenarios and their resulting likelihood of seeing this hypothetical smoker become a non-smoker by March 1995. As can be seen, the effects of taxes are not equal across groups of smokers; they are small in light smokers, more important in light-to-average smokers (the average in this sample being 14 cigarettes per day), almost inexistent in average smokers, and increase again slightly in heavy smokers-although the effects are reversed in this group. This is generally coherent with our expectations that light smokers will be more sensitive to taxes than heavier smokers, although not linearly so. This thus provides supports for P3.

Table 7a.

The influence of prior smoking level

\begin{tabular}{|c|c|c|c|c|c|c|c|}
\hline Predictor & B & S.E. & Wald(df) & Sig. & $\operatorname{Exp}(B)$ & $\begin{array}{r}\text { Hosmer \& } \\
\text { Lemeshow }\end{array}$ & $\begin{array}{r}\text { Cox \& Snell } \\
/ \\
\text { Nagelkerke } \\
\mathrm{R}^{2}\end{array}$ \\
\hline Original Model & & & & & & $30.862(7)^{* * *}$ & $.065 / .105$ \\
\hline $\begin{array}{l}\text { Smoking level in May } 94 \\
\text { (average number of } \\
\text { cigarettes smoked daily) }\end{array}$ & -.079 & .007 & 147.663(1) & $* * *$ & .924 & & \\
\hline Tax Cut (\$) & $\not a$ & & & & & & \\
\hline Tax Cut (\$) x Smoking Level & a & & & & & & \\
\hline Final Model & & & & & & $7.601(8) \mathfrak{x}$ & $.077 / .125$ \\
\hline $\begin{array}{l}\text { Smoking level in May } 94 \\
\text { (average number of } \\
\text { cigarettes smoked daily) }\end{array}$ & -.122 & .014 & $79.556(1)$ & $* * *$ & .885 & & \\
\hline Tax Cut (\$) & $x$ & & & & & & \\
\hline Tax Cut (\$) x Smoking Level & -.006 & .002 & $12.986(1)$ & $* * *$ & .994 & & \\
\hline Smoking Level ${ }^{2}$ & $\not a$ & & & & & & \\
\hline Tax Cut (\$) x Smoking Level ${ }^{2}$ & .001 & .000 & $13.939(1)$ & $* * *$ & 1.001 & & \\
\hline Smoking Level ${ }^{3}$ & .000 & .000 & $13.053(1)$ & $* * *$ & 1.000 & & \\
\hline Tax Cut (\$) x Smoking Level ${ }^{3}$ & .000 & .000 & $9.254(1)$ & .002 & 1.000 & & \\
\hline
\end{tabular}

$* * * p<.001 ; * * p<.01 ; * p<.05 ;+p<.10 ;$ n.s. = not significant 
Table 7b.

Likelihood of smoking cessation by tax cut and average daily cigarette consumption a year before

\begin{tabular}{crrrrrrr}
\hline & \multicolumn{7}{c}{ Average daily number of cigarettes smoked } \\
\cline { 2 - 8 } Tax Cut (\$) & 1 & 5 & 10 & 15 & 20 & 25 & 30 \\
\hline 5 & $71,7 \%$ & $41,2 \%$ & $23,0 \%$ & $14,5 \%$ & $10,3 \%$ & $8,2 \%$ & $7,4 \%$ \\
8 & $70,5 \%$ & $38,8 \%$ & $21,6 \%$ & $14,1 \%$ & $10,5 \%$ & $8,8 \%$ & $8,1 \%$ \\
11 & $69,2 \%$ & $36,5 \%$ & $20,3 \%$ & $13,7 \%$ & $10,7 \%$ & $9,4 \%$ & $8,8 \%$ \\
14 & $68,0 \%$ & $34,4 \%$ & $19,0 \%$ & $13,2 \%$ & $10,9 \%$ & $10,0 \%$ & $9,7 \%$ \\
17 & $66,9 \%$ & $32,4 \%$ & $17,8 \%$ & $12,8 \%$ & $11,1 \%$ & $10,7 \%$ & $10,6 \%$ \\
20 & $65,7 \%$ & $30,5 \%$ & $16,7 \%$ & $12,4 \%$ & $11,3 \%$ & $11,5 \%$ & $11,6 \%$ \\
\hline
\end{tabular}

The moderating influence of gender

Among the 2,851 respondents who were smokers in January of 1994, a total of 1,539 (or $54.0 \%$ ) were women. While 81 (i.e., 6.2\%) male smokers had stopped smoking by May 1994 and 280 (i.e., $21.3 \%$ ) by March 1995, seventy-nine (i.e., 5.1\%) female smokers had stopped smoking by May 1994 and 316 (i.e., 20.5\%) by March 1995. To statistically examine the effects of gender on the tax-behavior relationship postulated in P4, we first selected smokers as per January 1994 (prior to tax cuts). We then estimated a binary logistic regression model with May 1994 smoking status as a dependent variable and the tax cut in CAD\$ as a predictor. Gender was included as a covariate and an interaction factor with tax-level variables was created and introduced in each model. It should be noted that despite the discrepancies in the groups of quitters and stillsmokers, the number of respondents was sufficient to conduct analyses without having to under-sample the number of still-smokers (Peduzzi et al. 1996). All models were estimated using a stepwise, backward elimination process using Wald's method. The event of interest was for the dependent variable to take the value "being a non-smoker." We replicated the same analyses with the long-term smoking status as a dependent variable. Finally, we estimated the effects of the same predictors on non-smokers' propensity to start smoking, once again both in the short- and long-term, by replicating the same analyses after having first, this time, singled out those who declared to be non-smokers in January 1994 (prior to tax cuts).

Both In the short- and long-term, gender was not found to be a significant direct predictor or moderator of the effects of taxes on smoking cessation and only tax cuts (in \$) remained in the model ( $p<.05$; see Table 8 ). However, gender was a significant predictor and moderator of nonsmokers' propensity to remain non-smokers in the short-term such that men tended to be more likely to remain non-smokers but to be more sensitive to tax cuts $(p<.01)$. In the long-term, only the interaction between gender and tax cuts was a significant predictor of likelihood to remain a 
non-smoker $(p<.01)$. This suggests that men were less likely than women to remain non-smokers as taxes were cut deeper.

It should be noted that all four models had very low explanatory powers, in the order of $0.2 \%$ except in the short-term model explaining non-smokers' propensity to remain non-smokers which performed slightly better. Yet even in this latter case, the Nagelkerke pseudo- $\mathrm{R}^{2}$ was estimated at $1.4 \%$. In the case of non-smokers and their short-term behavior, it should also be noted that only 23 men and 38 women became smokers, which are very small samples. This could explain why no moderating influences are found. All in all, these analyses seem to suggest that gender plays a minor role in moderating the effects of taxes on behavioral change with regards to cigarettes, and also that tax cuts themselves, even when taking into account gender, are poor predictors of the propensity to change behaviors with regards to cigarette.

Table 8.

The moderating influence of gender on the tax-to-behavioral-change relationship (only models with significant relationships are reported)

\begin{tabular}{|c|c|c|c|c|c|}
\hline Predictor & B (S.E.) & Wald(df) & $\operatorname{Exp}(B)$ & $\begin{array}{r}\text { Hosmer \& } \\
\text { Lemeshow } \\
\end{array}$ & $\begin{array}{r}\text { Cox \& Snell / } \\
\text { Nagelkerke } \mathrm{R}^{2} \\
\end{array}$ \\
\hline \multicolumn{4}{|c|}{$\begin{array}{l}\text { Model: Short-Term From Smoker to Non-smoker } \\
\text { Gender (baseline = }\end{array}$} & $2.214(3) \not x$ & $.002 / .005$ \\
\hline Tax Cut $(\$)$ & $-.027(.012)$ & $5.067(1)^{*}$ & .974 & & \\
\hline Interaction effect & $\not$ & & & & \\
\hline \multicolumn{4}{|c|}{ Model: Short-Term Non-Smoker to remain Non-smoker } & $6.260(3) \not x$ & $.001 / .014$ \\
\hline Tax Cut (\$) & $\not$ & & & & \\
\hline Interaction effect & $-.094(.034)$ & $7.478(1)^{* *}$ & .910 & & \\
\hline $\begin{array}{l}\text { Model: Long-Term } \\
\text { Gender (baseline = } \\
\text { female) }\end{array}$ & oker to Non-s & moker & & $11.386(6)^{* *}$ & $.002 / .002$ \\
\hline Tax Cut (\$) & $-.013(.007)$ & $3.996(1)^{*}$ & .987 & & \\
\hline Interaction effect & $\not a$ & & & & \\
\hline \multicolumn{4}{|c|}{$\begin{array}{l}\text { Model: Long-Term Non-Smoker to remain Non-smoker } \\
\text { Gender (baseline = }\end{array}$} & $4.220(3) \not x$ & $.001 / .002$ \\
\hline Tax Cut $(\$)$ & $\not a$ & & & & \\
\hline Interaction effect & $-.020(.007)$ & $7.663(1)^{* *}$ & .980 & & \\
\hline
\end{tabular}


To investigate the effects of gender on the difference in the average daily consumption of cigarettes before and after tax cuts, we estimated a linear regression model with gender, tax cuts (\$), and a gender $\times$ tax cuts interaction term as predictor, using a backward elimination procedure. In the first step, none of the variables were significant predictors of behavioral change. In the last step, where only gender remained, the model was still not significant and gender was still not a significant predictor. This failed to provide support to P4c.

Table 9.

Propensity to behavioral change according to tax cuts and income

\begin{tabular}{|c|c|c|c|c|c|c|}
\hline Predictor & $B(S . E)$. & Wald(df) & Sig. & $\operatorname{Exp}(B)$ & $\begin{array}{r}\text { Hosmer \& } \\
\text { Lemeshow }\end{array}$ & $\begin{array}{r}\text { Cox \& Snell / } \\
\text { Nagelkerke } \mathrm{R}^{2}\end{array}$ \\
\hline \multicolumn{5}{|c|}{ Smokers' (Jan. 1994) propensity to become non-smokers (short-term) } & $7.282(8) \not$ & $.007 / .024$ \\
\hline Tax cut (\$) by Income & $-.013(.004)$ & $9.415(1)$ & .002 & .987 & & \\
\hline Income & $.300(.069)$ & $18.734(1)$ & $* * *$ & 1.349 & & \\
\hline \multicolumn{5}{|c|}{ Non-smokers' (Jan. 1994) propensity to remain non-smokers (short-term) } & $1.929(7) \not a$ & $.001 / .012$ \\
\hline Tax cut $(\$)$ & $-.068(.026)$ & $6.643(1)$ & .010 & .934 & & \\
\hline Tax cut (\$) by Income & $.011(.007)$ & $3.095(1)$ & .079 & 1.012 & & \\
\hline \multicolumn{5}{|c|}{ Smokers' (Jan. 1994) propensity to become non-smokers (long-term) } & $9.399(8) \not$ & $.004 / .007$ \\
\hline Tax cut (\$) & $-.032(.010)$ & $9.524(1)$ & .002 & .969 & & \\
\hline Tax cut (\$) by Income & $.007(.002)$ & $8.006(1)$ & .005 & 1.007 & & \\
\hline \multicolumn{5}{|c|}{ Non-smokers' (Jan. 1994) propensity to remain non-smokers (long-term) } & $9.914(7) \not a$ & $.001 / .005$ \\
\hline Tax cut $(\$)$ & $-.023(.010)$ & $5.395(1)$ & .020 & .978 & & \\
\hline Income & $-.080(.041)$ & $3.858(1)$ & .050 & .923 & & \\
\hline
\end{tabular}

$* * * p<.001 ; * * p<.01 ; * p<.05 ;+p<.10 ;$; $p>.10$ (n.s.)

The moderating effects of age and income

To investigate the effects of age and income on consumer response to tax cuts, we first had a look at the relationship between behavioral changes and age and revenue categories by generating plots putting in perspective these variables. In the case of income, we first isolated those for which we had revenue information available. Second-order and even third-order curvilinear relationships seemed to exist between age group and smoking status in both nonsmokers and smokers as per January 1994, except in the case of long-term behavior which appeared to be linearly-shaped. Income, on the other hand, appeared to be linearly related to smoking propensity. We therefore undertook to estimate models explaining smoking status in May 1994 and March 1995 as a function of, on one hand, age group and squared age group, and, on the other hand, income group for the two groups consisting of non-smokers and smokers in January 1994 respectively. We used all respondents for which information was available. Interaction terms between either age, age $^{2}$ or income group and tax cuts were 
introduced. To estimate the models, a stepwise, backward-elimination procedure using Wald's method was used.

As can be seen in Table 9, the models including tax cuts and income provided a good fit to the data but low explanatory power, with pseudo- $\mathrm{R}^{2}$ at less than $2.5 \%$. In the short-term, income was a strong and positive predictor of smoking cessation $(p<.001)$ and also a moderator of tax cuts' influence on smoking cessation $(p<.01)$. These results suggest that the higher the household income, the higher the propensity to quit smoking in the short-term, although a little less so as tax cuts get deeper. It also suggests that, in the short-term, tax cuts are less impactful than income on smokers' decision to quit smoking. Income however only marginally significantly moderated the impact of tax cuts on non-smokers propensity to remain non-smokers and only tax cuts were significant negative predictors of said propensity $(p<.01)$. In the long run, tax cuts were significant and negative predictors of smokers' propensity to quit smoking $(p<.01)$ but income moderated this relationship such that the higher the income, the lesser the impact of tax cuts on said propensity $(p<.01)$. In non-smokers, the long-term propensity to remain a nonsmoker was directly and negatively influenced by both tax cuts and income $(p<.05)$; the higher the income and/or the deeper the cuts, the lesser the propensity to remain a non-smoker in the long-run. P6a and P6c are therefore essentially supported except in the case of long-term nonsmokers' propensity to remain non-smokers, where income played a direct role and not a moderating one. The model estimating smokers' short-term propensity to become non-smokers also suggests a more important role for income as it is not a moderator of the effects of tax cuts but rather the opposite-that is, income drives propensity to quit smoking but is moderated by tax cuts.

To assess P6b, which contends that income will moderate the effects of tax cuts on smokers' daily consumption of cigarettes, we estimated a linear regression model with tax cuts, income, and a tax cut by income interaction term as predictors and the difference in smoked cigarettes between May 1994 and March 1995 as the dependent variable. A stepwise, backward elimination procedure was followed and yielded a model explaining $0.04 \%$ of the variance in which only household income was a significant and negative predictor $(p<.05)$. In other words, the higher the household revenue, the higher the difference in the average number of cigarettes smoked daily between May 1994 and March 1995. Tax cuts had no effect. This provides support for the role of income on smoking reduction but not as a moderator of the effects of tax cuts.

To investigate the role of age on behavioral change with regards to cigarettes, we first singled out smokers per January 1994 and estimated a model with the short-term non-smoker status as a dependent and tax cuts, age group, squared age group, and interactions between tax cuts and both age-related terms as predictors using a backward elimination procedure. As shown in Table 10 age $^{2}$ was a significant predictor of smokers' short-term propensity to quit smoking $(p<.001)$ and the negative value of the term suggests an inverse $U$-shaped relationship. Although counter-intuitive, tax cuts were found to be a significant and positive predictor of smokers' short-term propensity to become non-smokers $(p<.05)$. Age and age $^{2}$ were however significant moderators of tax cuts $(p<.001)$. For instance, as Table 11 shows, when taxes were cut by $\$ 5$, a 
16 year-old smoker had a $13.5 \%$ likelihood to quit smoking in the short term while a 37 year-old and a 60 year-old had a $5.3 \%$ and $2.9 \%$ such likelihood. Where taxes were cut by $\$ 20$, the same three smokers respectively had a $11.9 \%, 1,8 \%$, and $1.8 \%$ likelihood of having quit smoking in the short-term. We replicated these analyses to investigate non-smokers' short-term propensity to remain non-smokers. This time, when taking into account age, tax cuts were no longer a significant predictor of the likelihood to remain a non-smoker and only age ${ }^{2}$ remained $(p<.001)$.

Table 10.

Propensity to behavioral change according to tax cuts and age

\begin{tabular}{|c|c|c|c|c|c|c|}
\hline Predictor & $B(S . E)$. & Wald(df) & Sig. & $\operatorname{Exp}(B)$ & $\begin{array}{r}\text { Hosmer \& } \\
\text { Lemeshow }\end{array}$ & $\begin{array}{r}\text { Cox \& Snell / } \\
\text { Nagelkerke } \mathrm{R}^{2} \\
\end{array}$ \\
\hline \multicolumn{5}{|c|}{ Smokers' (Jan. 1994) propensity to become non-smokers (short-term) } & $4.582(8) \not$ & $.023 / .066$ \\
\hline Tax cuts $(\$)$ & $.047(.021)$ & $5.025(1)$ & .025 & 1.048 & & \\
\hline Tax cuts (\$) by Age & $-.065(.013)$ & $25.538(1)$ & $* * *$ & .937 & & \\
\hline $\mathrm{Age}^{2}$ & $-.041(.011)$ & $12.835(1)$ & $* * *$ & .960 & & \\
\hline Tax cuts (\$) by $\mathrm{Age}^{2}$ & $.009(.002)$ & $28.317(1)$ & $* * *$ & 1.009 & & \\
\hline \multicolumn{5}{|c|}{ Non-smokers' (Jan. 1994) propensity to remain non-smokers (short-term) } & $8.003(5) \not a$ & $.004 / .045$ \\
\hline $\mathrm{Age}^{2}$ & $.039(.009)$ & $19.868(1)$ & $* * *$ & 1.040 & & \\
\hline \multicolumn{5}{|c|}{ Smokers' (Jan. 1994) propensity to become non-smokers (long-term) } & $12.378(8) \not$ & $.026 / .041$ \\
\hline Tax cuts (\$) by Age & $-.003(.002)$ & $3.681(1)$ & .055 & .997 & & \\
\hline Age & $-.599(.093)$ & $41.694(1)$ & $* * *$ & .549 & & \\
\hline $\mathrm{Age}^{2}$ & $.061(.010)$ & $34.373(1)$ & $* * *$ & 1.062 & & \\
\hline \multicolumn{5}{|c|}{ Non-smokers' (Jan. 1994) propensity to remain non-smokers (long-term) } & $6.268(7) \not$ & $.023 / .084$ \\
\hline Tax cuts $(\$)$ & $-.033(.015)$ & $4.863(1)$ & .027 & .968 & & \\
\hline Tax cuts (\$) by Age & $.016(.008)$ & $3.935(1)$ & .047 & 1.016 & & \\
\hline $\mathrm{Age}^{2}$ & $.051(.009)$ & $30.723(1)$ & $* * *$ & 1.052 & & \\
\hline Tax cuts (\$) by Age ${ }^{2}$ & $-.002(.001)$ & $4.780(1)$ & .029 & .998 & & \\
\hline
\end{tabular}

$* * * p<.001 ; * * p<.01 ; * p<.05 ;+p<.10 ;$, p p $>.10$ (n.s.)

In long-term models, smokers' propensity to become non-smokers was also found to be significantly influenced by age and age ${ }^{2}$ only $(p<.001)$, although the tax cuts $\times$ age interaction term was marginally significant. In other words, age is a better predictor than tax cuts for smokers' propensity to quit smoking in the long-run, and not just a moderator of a tax cut influence. Finally, non-smokers' long-term propensity to remain non-smokers was strongly affected by age ${ }^{2}(p<.001)$, the positive B coefficient suggesting a $U$-shaped relationship between age and said propensity. Tax cuts and tax cuts $\times$ age and age ${ }^{2}$ interaction terms were also significant predictors of this propensity $(p<.05)$. This suggests that older non-smokers are less likely to remain non-smokers than younger non-smokers. To investigate whether the effects of 
tax cuts were in fact stronger in younger age groups, we estimated a model with propensity to remain non-smokers in the long run as a function of tax cuts for each age group separately. In all age groups, tax cuts failed to reach significance. Tax cuts only reached marginal significance in the group of 15-19 year-olds $(p=.078)$, suggesting that in this age group, non-smokers $(\mathrm{N}=$ $1,660)$ tended to react more strongly to tax cuts than other age groups, but neither significantly nor strongly so (Nagelkerke pseudo- $R^{2}=0.4 \%$ ). This suggests a very important contribution: when statistically controlling for age, tax cuts have virtually no impact on behavioral change with regards to smoking. This goes beyond P5a and P5c.

To investigate P5b, we estimated a linear regression model with the difference in cigarettes smoked daily between May 1994 and March 1995 as a dependent and age, tax cuts, and an age by tax cuts interaction term as predictors using a backward elimination procedure. After three iterations, only the tax cut by age interaction term remained $(p<.05)$. The model explained $0.1 \%$ of the variance but was significant. The negative parameter suggested that deeper tax cuts only had effects on daily cigarette consumption as smokers were older, although the small $\mathrm{R}^{2}$ statistic suggests that this effect itself is very limited. This provides empirical support for P5b but in the opposite direction than that postulated.

Table 11.

Smokers' Short-Term Propensity to Quit Smoking by Age and Depth of Tax Cut (\$)

\begin{tabular}{|c|c|c|c|c|c|c|c|c|}
\hline \multirow[b]{2}{*}{ Tax cuts } & \multicolumn{8}{|c|}{ Age group } \\
\hline & $\begin{array}{l}15-19 \\
\text { years }\end{array}$ & $\begin{array}{l}20-24 \\
\text { years } \\
\end{array}$ & $\begin{array}{l}25-34 \\
\text { years } \\
\end{array}$ & $\begin{array}{l}35-44 \\
\text { years } \\
\end{array}$ & $\begin{array}{l}45-54 \\
\text { years } \\
\end{array}$ & $\begin{array}{l}55-64 \\
\text { years }\end{array}$ & $\begin{array}{l}65-69 \\
\text { years }\end{array}$ & $70+$ years \\
\hline$\$ 5$ & $13,5 \%$ & $9,9 \%$ & $7,2 \%$ & $5,3 \%$ & $3,9 \%$ & $2,9 \%$ & $2,2 \%$ & $1,6 \%$ \\
\hline$\$ 7$ & $13,3 \%$ & $9,0 \%$ & $6,3 \%$ & $4,6 \%$ & $3,5 \%$ & $2,7 \%$ & $2,2 \%$ & $1,9 \%$ \\
\hline$\$ 9$ & $13,1 \%$ & $8,2 \%$ & $5,5 \%$ & $4,0 \%$ & $3,1 \%$ & $2,6 \%$ & $2,3 \%$ & $2,2 \%$ \\
\hline$\$ 11$ & $12,8 \%$ & $7,4 \%$ & $4,8 \%$ & $3,4 \%$ & $2,7 \%$ & $2,4 \%$ & $2,4 \%$ & $2,6 \%$ \\
\hline$\$ 13$ & $12,6 \%$ & $6,7 \%$ & $4,1 \%$ & $2,9 \%$ & $2,4 \%$ & $2,3 \%$ & $2,5 \%$ & $3,1 \%$ \\
\hline$\$ 15$ & $12,4 \%$ & $6,1 \%$ & $3,6 \%$ & $2,5 \%$ & $2,1 \%$ & $2,1 \%$ & $2,5 \%$ & $3,6 \%$ \\
\hline$\$ 17$ & $12,2 \%$ & $5,6 \%$ & $3,1 \%$ & $2,2 \%$ & $1,9 \%$ & $2,0 \%$ & $2,6 \%$ & $4,3 \%$ \\
\hline$\$ 20$ & $11,9 \%$ & $4,8 \%$ & $2,6 \%$ & $1,8 \%$ & $1,6 \%$ & $1,8 \%$ & $2,8 \%$ & $5,4 \%$ \\
\hline
\end{tabular}

The effects of prior tax levels

Our seventh and last proposition suggested that tax cuts should have more effects in smoking behavioral change when original tax cuts were higher. To investigate this, we estimated four different logistic regression models with tax cuts, initial tax levels, and an interaction term between the two as predictors and short-term or long-term smoker status as the dependent 
variable, in half the models singling out smokers as per January 1994 and in the other half using rather non-smokers as per January 1994.

As shown in Table 12, short-term behavior was only affected by the pre-cut tax level $(p<.05)$, suggesting that higher initial levels were influential in smoking cessation and propensity to remain a non-smoker and that cuts were not a short-term incentive to modify this tendency. In the long-run, smokers' quitting behavior was significantly related to neither tax cuts nor initial taxes while the interaction term between initial taxes and tax cuts was a significant and negative predictor of non-smokers' long-term propensity to remain non-smokers. This suggests that deeper tax cuts were deterrents to remaining non-smokers only in those provinces where original taxes were high $(p<.05)$. In all cases, Nagelkerke pseudo- $\mathrm{R}^{2}$ were below $0.9 \%$, suggesting that despite significance of some of the variables, they really exerted very little influence in smokers' and non-smokers propensities to change behaviors. This provides limited support to P7a and c.

Table 12.

Propensity to behavioral change according to tax cuts and initial taxes

\begin{tabular}{|c|c|c|c|c|c|c|}
\hline Predictor & $B(S . E)$. & Wald(df) & Sig. & $\operatorname{Exp}(B)$ & $\begin{array}{r}\text { Hosmer \& } \\
\text { Lemeshow }\end{array}$ & $\begin{array}{r}\text { Cox \& Snell / } \\
\text { Nagelkerke } \\
\mathrm{R}^{2} \\
\end{array}$ \\
\hline \multicolumn{5}{|c|}{ Smokers' (January 1994) Short-Term Propensity to Quit Smoking } & $8.994(5) \not$ & $.002 / .006$ \\
\hline Initial Taxes (\$) & $.058(.023)$ & $6.603(1)$ & .010 & 1.060 & & \\
\hline \multicolumn{5}{|c|}{ Non-Smokers' (January 1994) Short-Term Propensity to Remain Non-Smokers } & $2.800(5) \not$ & $.001 / .008$ \\
\hline Initial Taxes (\$) & $.094(.044)$ & $4.543(1)$ & .033 & 1.098 & & \\
\hline \multicolumn{5}{|c|}{ Smokers' (January 1994) Long-Term Propensity to Quit Smoking } & $8.974(6) \not x$ & $.003 / .004$ \\
\hline Initial Taxes (\$) by Tax Cuts & $-.005(.003)$ & $3.461(1)$ & .063 & .995 & & \\
\hline Tax cuts $(\$)$ & $.125(.074)$ & $2.802(1)$ & .094 & 1.133 & & \\
\hline \multicolumn{5}{|c|}{ Non-Smokers' (January 1994) Long-Term Propensity to Remain Non-Smokers } & $11.997(5)^{*}$ & $.001 / .003$ \\
\hline Initial Taxes (\$) by Tax Cuts & $-.001(.000)$ & $5.658(1)$ & .017 & .999 & & \\
\hline
\end{tabular}

$* p<.05 ;$; n.s.

To investigate $\mathrm{P} 7 \mathrm{~b}$, we estimated a linear regression model with tax cuts, initial tax levels, and an interaction term between the two as predictors and the difference in the daily number of cigarettes smoked between May 1994 and May 1995 as the dependent variable following a backward elimination procedure. None of the predictors could reach statistical significance, suggesting that the level of cigarette consumption is not affected by tax cuts, original tax levels, or any interaction between the two, failing to provide empirical support to P7b. 


\section{Discussion}

The extent literature pertaining to the effects of tax policy on cigarette consumption had generally not investigated the context of a tax decrease, let alone that of differential decrease within a same country. This study provides one of the first comprehensive, contingent analyses of the impact of tax cuts on short-term and long-term behavioral modification of both smokers and non-smokers.

The results of our analyses suggest a number of conclusions (see Appendix 1). First, certainly the most robust results pertain to the effects of taxes on consumption of smuggled or foreignbought cigarettes. The models present relatively high pseudo- $\mathrm{R}^{2}$ statistics $(17 \%$ to $23 \%$ in the case of smuggling cessation, and $6.7 \%$ to $7 \%$ in the case of smuggling beginning) and a good fit to the data. They suggest that lower final levels of taxes (post-rollback) and deeper cuts translate into more important cessation of consumption of smuggled cigarettes and lesser likelihood of resorting to this behavior in those who did not prior to tax cuts. Conversely, higher final levels of taxes and shallower cuts translate into less cessation of consumption of smuggled cigarettes and a higher likelihood to start consuming smuggled cigarettes in those who did not beforehand.

Our results also tend to suggest that age plays a significant role in explaining smokers' and nonsmokers' behavior. In fact, after controlling for age, taxes loose essentially all explanatory power. In the case of non-smokers, contrary to our expectations, older individuals are actually more sensitive to tax cuts than younger individuals.

Another variable that tends to very significantly affect smokers' propensity to quit smoking is their previous smoking level. The higher the number of cigarettes smoked daily, the less likely a smoker is to quit, which is really a tax-independent phenomenon.

Finally, the rest of our results essentially suggest that the 1994 tax rollbacks have had much impact on neither smokers' propensity to quit smoking nor non-smokers' propensity to remain non-smokers. Indeed, when sample sizes are large and p-values high, as is the case for all taxrelated variables in all of the models that we estimated, influences may turn to be statistically significant despite very small effect sizes. The very low explanatory power of our models, as expressed by the various Cox $\&$ Snell and/or Nagelkerke pseudo- $R^{2}$ statistics, tends to confirm this except in the case of smuggling behavior as well as in the models that take into account previous smoking levels and/or age.

Moreover, in several instances, our results suggested counterintuitive relationships between taxes and behavior, such as higher propensities to quit when taxes were lower. This discrepancy provides additional ground to the suggestion that other very powerful predictors, such as antitobacco sentiment (Keeler, Hu et al, 2001; Lance, Akin et al, 2004; Alamar and Glantz, 2006; Marlow, 2007) or concern for current or future health, might perform better at explaining 
smoking behavioral change than taxes. In fact, although not analyzed in this research, in this same survey by Statistics Canada, consequences on current and future health came as the number 1 and number 2 reasons for quitting or reducing cigarette consumption in all 4 cycles of the research (Ouellet 2010). This should warrant further, more comprehensive research on the topic of smoking cessation, reduction, and their opposite behaviors on the basis of not only taxes but also such variables as investments in societal advertising, presence of messages on cigarette packs, and other social measures.

This research also presents some limitations that should be taken into account when considering its outcomes. First, the data that was used dates back to 1994. Despite the fact that it is a very unique database and that it was compiled by a Canadian Federal Agency, consumption behaviors have likely evolved over the past 15 years such that other factors can possibly play more important roles today. Considering the legislative and regulatory changes that have been implemented federally in Canada as well as locally in each of the 10 Canadian provinces, such as bans on smoking in public places and warnings on cigarette packs, the results could be different today should this survey be conducted again, very likely showing an even smaller role of taxes on smoking behavior. Finally, the survey methodology does not entirely allow causal estimations to be considered as several other factors were not measured and thus included in the analysis, most importantly the level of investment in social advertising, legislation with regards to smoking activities in the various provinces, and so on. 
Appendix 1.

Results of the Empirical Test of our Propositions

\begin{tabular}{|c|c|c|c|}
\hline \multicolumn{2}{|c|}{ Proposition } & \multirow{2}{*}{$\begin{array}{l}\text { Results } \\
\text { Supported }\end{array}$} & \multirow{3}{*}{$\begin{array}{l}\text { Comments } \\
\text { Although the models show } \\
\text { statistically significant effects } \\
\text { of taxes in the short- and long } \\
\text { term, the explanatory power } \\
\text { of these models is very low } \\
(<0.5 \%)\end{array}$} \\
\hline P1a & $\begin{array}{l}\text { At the individual level, the more important } \\
\text { the decrease in cigarette taxes, the higher } \\
\text { the propensity to begin smoking. }\end{array}$ & & \\
\hline P1b & $\begin{array}{l}\text { At the individual level, the more important } \\
\text { the decrease in cigarette taxes, the lesser } \\
\text { the propensity to quit smoking. }\end{array}$ & Supported & \\
\hline P1c & $\begin{array}{l}\text { At the individual level, the more important } \\
\text { the decrease in cigarette taxes, the lesser } \\
\text { the propensity to reduce smoking. }\end{array}$ & $\begin{array}{c}\text { Not } \\
\text { supported }\end{array}$ & \\
\hline $\mathrm{P} 2 \mathrm{a}$ & $\begin{array}{l}\text { At the individual level, within smokers, } \\
\text { lower final taxes as well as a tax and/or } \\
\text { price decrease should lead to a higher } \\
\text { propensity stop consuming smuggled } \\
\text { cigarettes. }\end{array}$ & Supported & \\
\hline $\mathrm{P} 2 \mathrm{~b}$ & $\begin{array}{l}\text { At the individual level, within smokers, } \\
\text { lower final taxes as well as a tax and/or } \\
\text { price decrease should lead to a lower } \\
\text { propensity to start consuming smuggled } \\
\text { cigarettes. }\end{array}$ & Supported & \\
\hline P3 & $\begin{array}{l}\text { At the individual level, heavy smokers' } \\
\text { behavior should be less affected by a tax } \\
\text { and/or price decline than light smokers' } \\
\text { behavior. }\end{array}$ & Supported & $\begin{array}{l}\text { In fact, the effects in heavy } \\
\text { smokers are counter to our } \\
\text { expectations. Moderate } \\
\text { smokers appear not sensitive } \\
\text { to taxes. }\end{array}$ \\
\hline P4a & $\begin{array}{l}\text { At the individual level, in the case of a tax } \\
\text { and/or price decrease, women's } \\
\text { propensity to start smoking should be } \\
\text { higher than men's propensity to start } \\
\text { smoking. }\end{array}$ & $\begin{array}{c}\text { Partially } \\
\text { supported }\end{array}$ & $\begin{array}{l}\text { In the short-term, men tended } \\
\text { to be more likely to remain } \\
\text { non-smokers but to be more } \\
\text { sensitive to tax cuts. In the } \\
\text { long-term, only men were less }\end{array}$ \\
\hline P4b & $\begin{array}{l}\text { At the individual level, in the case of a tax } \\
\text { and/or price decrease, women's } \\
\text { propensity not to quit smoking should be } \\
\text { higher than men's propensity to increase } \\
\text { smoking behavior. }\end{array}$ & $\begin{array}{c}\text { Not } \\
\text { supported }\end{array}$ & $\begin{array}{l}\text { as taxes were cut deeper. } \\
\text { Women are therefore } \\
\text { apparently not sensitive to } \\
\text { taxes. The explanatory power } \\
\text { of these models is also very } \\
\text { low }(<0.5 \%) \text {. }\end{array}$ \\
\hline
\end{tabular}




\begin{tabular}{|c|c|c|c|}
\hline \multicolumn{2}{|c|}{ Proposition } & \multirow{2}{*}{$\begin{array}{l}\text { Results } \\
\text { Not } \\
\text { supported }\end{array}$} & \multirow[t]{2}{*}{ Comments } \\
\hline P4c & $\begin{array}{l}\text { At the individual level, in the case of a tax } \\
\text { and/or price decrease, women's } \\
\text { propensity to increase their cigarette } \\
\text { consumption should be higher than men's } \\
\text { propensity to increase smoking behavior. }\end{array}$ & & \\
\hline P5a & $\begin{array}{l}\text { At the individual level, age should } \\
\text { moderate the tax-to-behavior relationship } \\
\text { postulated in P1 such that younger } \\
\text { individuals should have a higher propensity } \\
\text { to start smoking in the case of a tax and/or } \\
\text { price decrease. }\end{array}$ & Supported & $\begin{array}{l}\text { In fact, after controlling for } \\
\text { age, taxes loose essentially all } \\
\text { explanatory power. }\end{array}$ \\
\hline P5b & $\begin{array}{l}\text { At the individual level, age should } \\
\text { moderate the tax-to-behavior relationship } \\
\text { postulated in P1 such that younger } \\
\text { individuals should have a higher propensity } \\
\text { to increase smoking in the case of a tax } \\
\text { and/or price decrease. }\end{array}$ & $\begin{array}{c}\text { Not } \\
\text { supported }\end{array}$ & $\begin{array}{l}\text { A significant relationship is } \\
\text { found but in the opposite } \\
\text { direction (older smokers are } \\
\text { more sensitive to taxes). }\end{array}$ \\
\hline P5c & $\begin{array}{l}\text { At the individual level, age should } \\
\text { moderate the tax-to-behavior relationship } \\
\text { postulated in P1 such that younger } \\
\text { individuals should have a higher propensity } \\
\text { not to quit smoking in the case of a tax } \\
\text { and/or price decrease. }\end{array}$ & Supported & $\begin{array}{l}\text { In fact, after controlling for } \\
\text { age, taxes loose essentially all } \\
\text { explanatory power. }\end{array}$ \\
\hline P6a & $\begin{array}{l}\text { At the individual level, income should } \\
\text { moderate the tax-to-behavior relationship } \\
\text { postulated in } \mathrm{P} 1 \text { such that lower-income } \\
\text { individuals should have a higher propensity } \\
\text { to start smoking in the case of a tax and/or } \\
\text { price decrease. }\end{array}$ & $\begin{array}{c}\text { Not } \\
\text { supported }\end{array}$ & $\begin{array}{l}\text { The explanatory power of } \\
\text { these models is also very low } \\
(<0.5 \%) \text {. }\end{array}$ \\
\hline P6b & $\begin{array}{l}\text { At the individual level, income should } \\
\text { moderate the tax-to-behavior relationship } \\
\text { postulated in } \mathrm{P} 1 \text { such that lower-income } \\
\text { individuals should have a higher propensity } \\
\text { to increase smoking in the case of a tax } \\
\text { and/or price decrease. }\end{array}$ & $\begin{array}{c}\text { Not } \\
\text { supported }\end{array}$ & \\
\hline P6c & $\begin{array}{l}\text { At the individual level, income should } \\
\text { moderate the tax-to-behavior relationship } \\
\text { postulated in P1 such that lower-income } \\
\text { individuals should have a higher propensity } \\
\text { not to quit smoking in the case of a tax } \\
\text { and/or price decrease. }\end{array}$ & Supported & $\begin{array}{l}\text { In fact, the main effects of } \\
\text { income are very strong, } \\
\text { although moderated by tax } \\
\text { cuts. The explanatory power } \\
\text { of these models is also low } \\
(<2.5 \%) \text {. }\end{array}$ \\
\hline
\end{tabular}




\begin{tabular}{lll}
\hline Proposition & Results & Comments \\
\hline & At the individual level, in the case of a tax & $\begin{array}{l}\text { In the long-term model only } \\
\text { (in the short-term, higher }\end{array}$ \\
P7a cut, higher initial tax levels should & Supported & $\begin{array}{l}\text { initial taxes lead to a higher } \\
\text { propensity to remain a non- } \\
\text { translate into a higher propensity to start } \\
\text { smoking than lower initial tax levels. }\end{array}$ \\
& $\begin{array}{l}\text { smoker). The model explains } \\
0.8 \% \text { of variance. }\end{array}$
\end{tabular}

At the individual level, in the case of a tax cut, higher initial tax levels should

P7b translate into a higher propensity to increase smoking than lower initial tax

Not

supported levels.

At the individual level, in the case of a tax

P7c cut, higher initial tax levels should translate into a higher propensity not to quit smoking than lower initial tax levels.
In the short-term, only initial taxes are significant in explaining propensity to stop smoking. Nothing is significant in the long-term model. 


\section{References}

Abernethy, A. M. and J. E. Teel (1986). "Advertising Regulation's Effect upon Demand for Cigarettes." Journal of Advertising 15(4): 51.

Adda, J. and F. Cornaglia (2006). "Taxes, Cigarette Consumption, and Smoking Intensity." The American Economic Review 96(4): 1013.

Ahrens, D. M. (2009). "TOBACCO TAXES AND CIGARETTE CONSUMPTION IN LOW INCOME POPULATIONS." American Journal of Public Health 99(1): 6.

Alamar, B. and S. A. Glantz (2006). "Effect of Increased Social Unacceptability of Cigarette Smoking on Reduction in Cigarette Consumption." American Journal of Public Health 96(8): 1359.

Andrews, R. L. and G. R. Franke (1991). "The Determinants of Cigarette Consumption: A MetaAnalysis." Journal of Public Policy \& Marketing 10(1): 81.

Baltagi, B. H. and D. Levin (1986). "Estimating Dynamic Demand for Cigarettes Using Panel Data: The Effects of Bootlegging, Taxation and Advertising Reconsidered." The Review of Economics and Statistics 68(1): 148.

Barnett, P. G., T. E. Keeler, et al. (1995). "Oligopoly structure and the incidence of cigarette excise taxes." Journal of Public Economics 57(3): 457.

Beatty, T., E. Larsen, et al. (2009). "Driven to drink: Sin taxes near a border." Journal of Health Economics 28(6): 1175.

Berg, G. D. and W. H. Kaempfer (2001). "Cigarette demand and tax policy for race groups in South Africa." Applied Economics 33(9): 1167.

Carpenter, C. and P. Cook (2008). "Cigarette taxes and youth smoking: New evidence from national, state, and local Youth Risk Behavior Surveys." Journal of Health Economics 27(2): 287.

Cavana, R. and M. Tobias (2008). "Integrative system dynamics: analysis of policy options for tobacco control in New Zealand." Systems Research and Behavioral Science 25(5): 675.

Chaloupka, F. (1992). "Clean Indoor Air Laws, Addiction and Cigarette Smoking." Applied Economics 24(2): 193.

Chapman, S. and J. Richardson (1990). "Tobacco Excise and Declining Tobacco Consumption: The Case of Papua New Guinea." American Journal of Public Health 80(5): 537.

Chen. Tao. Baohong Sun. and Singh. Vishal (2009). "An Empirical Investigation of the Dynamic Effect of Marlboro's Permanent Pricing Shift." Marketing Science. 28(4). 740-758. 
Delnevo, C. D., J. Foulds, et al. (2005). "TRADING TOBACCO: ARE YOUTHS CHOOSING CIGARS OVER CIGARETTES?" American Journal of Public Health 95(12): 2123.

Duffy, M. (2006). "Tobacco consumption and policy in the United Kingdom." Applied Economics 38(11): 5 .

Farrelly, M. C., J. W. Bray, et al. (2001). "Response by adults to increases in cigarette prices by sociodemographic characteristics." Southern Economic Journal 68(1): 156.

Farrelly, M. P., M. B. Engelen, et al. (2008). "Cigarette Prices, Smoking, and the Poor, Revisited/Franks et al. respond." American Journal of Public Health 98(4): 582.

Flewelling, R. L., E. Kenney, et al. (1992). "First-Year Impact of the 1989 California Cigarette Tax Increase on Cigarette Consumption." American Journal of Public Health 82(6): 867.

Galbraith, J. W. and M. Kaiserman (1997). "Taxation, smuggling and demand for cigarettes in Canada: Evidence from time-series data." Journal of Health Economics 16(3): 287.

Gillespie. K. (2000). "Talk of tax hike cheers anti-smoke lobby --- Spectre of smuggling rises as governments discuss raising tax to pre-'94 levels." Toronto Star. May 13.

Goel, R. K. and M. A. Nelson (2006). "The Effectiveness of Anti-Smoking Legislation: A Review." Journal of Economic Surveys 20(3): 325.

Gray C. (1994). "The tobacco-tax rollback may end the smuggling. but what will it do to our health?" Canadian Medical Association Journal. 150. 1295-6.

Gruber, J., A. Sen, et al. (2003). "Estimating price elasticities when there is smuggling: The sensitivity of smoking to price in Canada." Journal of Health Economics 22(5): 821.

Hamilton, Vivian H., Levington, Carey, St-Pierre, Yvan, and Grimard, Franque (1997), "The effect of tobacco tax cuts on cigarette smoking in Canada," Canadian Medical Association Journal, 156(2), 187-191.

Hu, T.-w., H.-Y. Sung, et al. (1995). "Reducing cigarette consumption in California: Tobacco taxes vs an anti-smoking media campaign." American Journal of Public Health 85(9): 1218.

Kaiserman, M. J. and B. Rogers (1991). "Tobacco Consumption Declining Faster in Canada than in the US." American Journal of Public Health 81(7): 902.

Keeler, T. E., T.-W. Hu, et al. (2001). "State tobacco taxation, education and smoking: Controlling for the effects of omitted variables." National Tax Journal 54(1): 83.

Lance, P. M., J. S. Akin, et al. (2004). "Is cigarette smoking in poorer nations highly sensitive to price? Evidence from Russia and China." Journal of Health Economics 23(1): 173. 
Lee, Chen, et al. (2009). "Price sensitivity and smoking smuggled cigarettes." European Journal of Public Health 19(1): 23.

Levy, D. and N. Sheflin (1985). "The Demand for Alcoholic Beverages: An Aggregate Time-Series Analysis." Journal of Public Policy \& Marketing 4: 47.

Loh, C., C. Chen, et al. (2009). "Multiple Dimensions of Cigarette Smoking and Responsiveness to Cigarette Price Changes in Taiwan." Journal of Family and Economic Issues 30(2): 203.

Long, J.S. (1997), Regression Models for categorical and limited dependent variables, Thousand Oaks, CA: Sage Publications.

Lovenheim, M. (2008). "How Far to the Border?: The Extent and Impact of Cross-Border Casual Cigarette Smuggling." National Tax Journal 61(1): 7.

Macki, S. (2002). "Cigarette consumption in different U.S. states, 1955-1998: An empirical analysis of the potential use of excise taxation to reduce smoking." Journal of Consumer Policy 25(1): 89.

Marlow, M. (2007). "Do Tobacco-Control Programs Lower Tobacco Consumption?" Public Finance Review 35(6): 689.

Mindell, J. S. and D. K. Whynes (2000). "Tobacco. Cigarette consumption in The Netherlands 1970-1995: does tax policy encourage the use of hand-rolling tobacco?" European Journal of Public Health 10(3): 214.

Musgrave, S. and N. Stern (1988). "Alcohol: Demand and Taxation Under Monopoly and Oligopoly in South India in the 1970s." Journal of Development Economics 28(1): 1.

Nicolás, Á. L. and J. P. Domínguez (2006). "Policies for the prevention of cigarette consumption: the case of Spain." International Journal of Consumer Studies 30(3): 271.

Nikolay, G. and I. Ian (2005). "A 'long march' perspective on tobacco use in Canada." The Canadian Journal of Economics 38(2): 366.

Novotny, T. E. and M. B. Siegel (1996). "California's tobacco control saga." Health Affairs 15(1): 58.

Ogloblin, C. and G. Brock (2003). "Smoking in Russia: The 'Marlboro Man' Rides but Without 'Virginia Slims' for Now." Comparative Economic Studies 45(1): 87.

Ouellet, Jean-François (2010), L'échec des politiques de taxation à combattre le tabagisme: Les résultats de l'enquête de Statistique Canada de 1994. Unpublished Working Paper, HEC Montréal. 
Peduzzi, P., Concato, J., Kemper, E., Holford, T.R., and Feinstein, A.R. (1996), "A simulation study of the number of events per variable in logistic regression analysis," Journal of Clinical Epidemiology 49, 1373-1379.

Peter, B. and O. Nilss (1999). "Cigarette and tobacco consumption: Have anti-smoking policies made a difference?" Economic Record 75(230): 225.

RCMP (2010). Illicit Tobacco Statistics. [online at http://www.rcmp-grc.gc.ca/ce-da/tobactabac/stats-eng.htm] accessed March 9. 2010.

Saba, R. P., T. R. Beard, et al. (1995). "The demand for cigarette smuggling." Economic Inquiry 33(2): 189.

Seldon, B. J. and R. Boyd (1991). "The Stability of Cigarette Demand." Applied Economics 23(2): 319.

Statistics Canada (1995). Survey on Smoking in Canada. microdata user's guide. Ottawa: Special Surveys Division. StatCan. Cat no 82M0008G3.

Sung, H.-Y., T.-W. Hu, et al. (1994). "Cigarette taxation and demand: An empirical model." Contemporary Economic Policy 12(3): 91.

Tauras, J., L. Powell, et al. (2007). "The demand for smokeless tobacco among male high school students in the United States: the impact of taxes, prices and policies." Applied Economics 39(1): 31.

van der Merwe, R. and I. Abedian (1999). "A reduction in consumer expenditure on cigarettes and its effects on employment: A case study of South Africa." Contemporary Economic Policy 17(3): 412.

Wasserman, J., W. G. Manning, et al. (1991). "The Effects of Excise Taxes and Regulations on Cigarette Smoking; The Demand for Cigarettes." Journal of Health Economics 10(1): 43.

Wilcox. Keith. Kim. Hyeong Min. and Sen. Sankar (2009). "Why Do Consumers Buy Counterfeit Luxury Brands?" Journal of Marketing Research. 46 (2). 247-259.

Young, T. (1983). "The Demand for Cigarettes: Alternative Specifications of Fujii's Model." Applied Economics 15(2): 203. 